\title{
Carol Robinson
}

\author{
Identifying things small and large in one mass spec experiment, and why persistence matters.
}

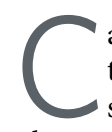
arol Robinson has pioneered the development of native mass spectrometry in the face of strong skepticism, says Wolfgang Baumeister, director of molecular structural biology at the Max Planck Institute of Biochemistry. He has collaborated and coauthored with Robinson and long respected her work. "This is a wonderful example of how persistence can pay off in science," he says. Robinson says she encourages her mentees to have stamina and to say: "It's not working yet.' The 'yet' word is so important, I think, there will be a way, we'll get it to work."

The prototype of the new Tribrid mass spectrometer, with all its bells and whistles, sits quietly alongside others in Robinson's now darkened University of Oxford lab. The team worked with Thermo Fisher to develop the instrument, the Orbitrap Eclipse Tribrid Mass Spectrometer. Due to COVID-19, Robinson has had to close the lab. "It's sort of heartbreaking," she says. The lab and her work, "it's my passion and my joy." She would prefer to study how SARS-CoV-2 enters cells and find drugs to thwart it. "But to do that puts people at risk, so we can't do that at the moment." She has donated equipment to local medical labs, and some lab members are volunteering their expertise.

Beside her position in Oxford's chemistry department as Doctor Lee's Professor of Chemistry, she is president of the Royal Society of Chemistry, was the first female chemistry professor at Oxford, was previously the first female professor of chemistry at the University of Cambridge and was appointed Dame Commander of the Order of the British Empire. "I trained as a chemist, I love biology, and I'm passionate about mass spec," she says. At age 16, she tested out of school, joined Pfizer as a lab technician and felt immediately at home with a mass spectrometer. She studied chemistry part time, left Pfizer and obtained her master's degree, and continued at Cambridge, where she competed her $\mathrm{PhD}$ in the lab of Dudley Williams. She took an eight-year child-rearing break and returned to science as a postdoctoral fellow at Oxford, followed by her appointment at Cambridge and her return to Oxford.

When her lab reopens, she will relish the simultaneity of experimental design the new mass spec enables. Proteins tend to not practice social distancing. In the cell,

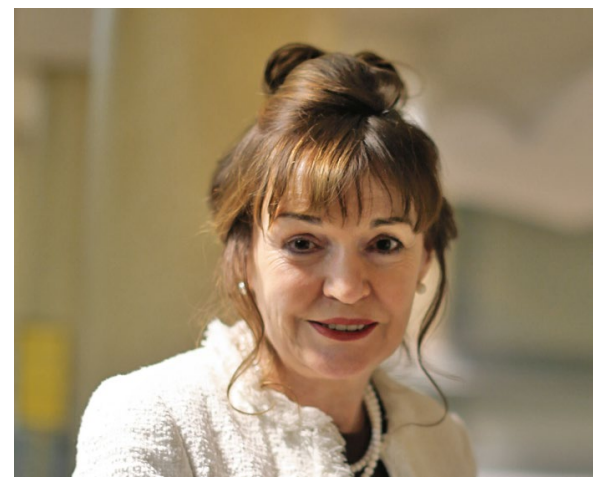

Carol Robinson. Credit: J. Allison

assemblies of proteins have associates, such as lipids. Now it's possible to determine, all at once, which small molecule associates shape an assembly's behavior. Researchers no longer need to take a complex, extract its intrinsic or externally added associates and analyze them with high-performance liquid chromatography or another platform. "Now we can say: 'let's keep it all together,' she says. "Let's dissociate it, or break it up, inside this mass spectrometer." What was once an affair of multiple experiments is now one.

Joseph Gault and Idlir Liko from her lab decamped to Thermo Fisher to help hone the instrument, three years in the making. They needed, for example, to increase activation energies that shape molecular fragmentation and engineer the way ions and fragments are accelerated and routed. "It wasn't just a single parameter change," says Robinson. The instrument's focus has to be on the entire complex and the ligands. "That was kind of the transformational step," she says. Multiple interlinked parameters had to be changed at the same time.

Users will need to tailor those interlinked parameters in their experiments, says Robinson. Some might try to find a target of a particular drug, which might not be readily seen, even at high resolution, with, say, cryoelectron microscopy. Researchers will be able to find and obtain accurate identifying data on, for example, lipids, metabolites or regulatory cofactors that are a protein assembly's binding partners, whether of the steady or transient kind. They can look into the 'unknown density' in their electron microscopy maps. Thus far, she has received many user messages, such as from electron microscopy labs wondering about some unknown protein associates.

Her lab presents data on a bacterial outer membrane protein, chosen for its ability to multi-task, says Robinson. It binds to an antibiotic, a lipid and a drug that blocks the pore. The team wanted to show that the platform could discover all three, and in a semi-automated way, without having been instructed to do so. The instrument enables, as the lab has named it, nativeomics, which lets people discover assemblies plus partners de novo and then explore function. Many protein complexes have unknown function, but finding a small-molecule associate such as, say, dopamine hints that a protein complex could be a dopamine transporter.

\section{"I trained as a chemist, I love biology, and I'm passionate about mass spec."}

In the age of COVID-19, Robinson has virtual meetings about science also as she consults for the spinout she founded, OMass Therapeutics, which has received series A funding from investment company Syncona, the University of Oxford and Oxford Sciences Innovation. The company gives interested lab members a whiff of industry, which helps with career decisions.

Robinson gets ideas on runs. Because of COVID-19, she now likes winding down the week with virtual social catchups. She would enjoy imaginary virtual tea with Marie Curie, whom she likes because Curie was ahead of her time as a woman in science. Another invitee would be Joseph John Thomson, who separated two low-molecular-weight isotopes in the first mass spec experiment. "Now I'd like to say, 'you know, look what you started,' says Robinson.

\section{Vivien Marx}

Published online: 4 May 2020

https://doi.org/10.1038/s41592-020-0824-X

Reference

Gault, J. et al. Combining native and 'omics' mass spectrometry to identify endogenous ligands bound to membrane proteins. Nat. Methods https://doi. org/10.1038/s41592-020-0821-0 (2020). 